\title{
Tissue adhesive innovations derived from the natural world
}

\author{
Craig R. Smith, MD \\ From the Department of Surgery, College of Physicians \& Surgeons of Columbia University, Columbia University \\ Medical Center of New York Presbyterian Hospital, New York, NY. \\ Received for publication Aug 29, 2017; accepted for publication Sept 2, 2017; available ahead of print Nov 9, \\ 2017. \\ Address for reprints: Craig R. Smith, MD, Department of Surgery, College of Physicians \& Surgeons of Columbia \\ University, Columbia University Medical Center of New York Presbyterian Hospital, 177 Fort Washington Ave, \\ Milstein Building, 7th Floor, 7GN-435, New York, NY 10032 (E-mail: crs2@ columbia.edu). \\ J Thorac Cardiovasc Surg 2018;155:278-9 \\ $0022-5223 / \$ 36.00$ \\ Copyright (C) 2017 Published by Elsevier Inc. on behalf of The American Association for Thoracic Surgery \\ https://doi.org/10.1016/j.jtcvs.2017.09.014
}

When sutures break or pull through tissue, a manageable challenge can become a mortal catastrophe. At such times, tissue adhesives have tremendous appeal in cardiac surgery, and in other varieties of soft tissue surgery (lung, liver, pancreas) as well. An adhesive that will work for soft tissue must stick when wet and must retain enough flexibility to conform to an irregular, moving surface. The wetness of bleeding in the heart, great vessels, and liver sets a very high bar. In desperate, finger-in-the-dike crises, some cardiac surgeons, including me, have resorted to departmentstore cyanoacrylates (Super Glue, KrazyGlue); however, the ingredients are toxic, the end products are rigid, and they do not adhere to wetness. Products that use glutaraldehyde to generate amine-aldehyde covalent bonds, although mechanistically more biologic, have similar shortcomings. A wide array of topical hemostatic agents that depend on synergy with in vivo clotting systems to promote hemostasis and achieve minor degrees of adhesiveness are applied liberally, at great expense, in many operating rooms. Most of these agents, not quite fairy dust, excel at stopping ooze that will probably stop anyway, and at covering up bleeding that will need some definitive treatment, at some inconvenient time later.

My Eureka moment came many years ago, at a point in my career when the need for good tissue adhesives was very fresh in mind. I was all-too-frequently struggling to manage catastrophic bleeding in heart-lung transplants and aortic dissections, with the occasional posterior ventricular rupture thrown in. On a walk through woods in rain, I ploughed through a spider web, and was struck by how the web was immediately and tenaciously plastered to my face. Biologic systems, I thought, solve this problem all the time-they stick when wet, and they retain flexibility. It seemed likely that the answers lay in substances found in nature.

True to form, I did nothing personally to pursue this inspiration! Fortunately, it was not mine alone, and through the decades, biodegradable, biocompatible spider silk, native and recombinant, has been studied in a wide range of extra-arachnid applications, including drug delivery

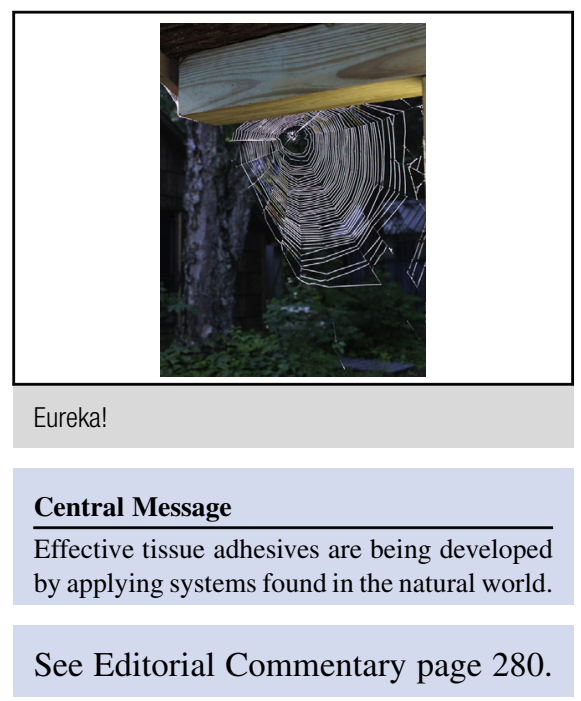

systems and tissue engineering scaffolds. ${ }^{1}$ I've kept my eyes open for similarly inspired translational products, and I couldn't fail to be intrigued by a recent report in $\mathrm{Na}$ ture that introduces a relatively new twist to the engineering of tissue adhesives-rather than depending on chemical bonds, Baik and coauthors ${ }^{2}$ translate the mechanical function of octopus suction cups into potentially valuable tissue adhesives. This is reminiscent of approaches inspired by the gravity-defying feet of geckos, except that meticulous biophysical studies have proved what every zookeeper and gardener with a mist-sprayer already knew-geckos fall off wet walls and ceilings. The complex setae and microfibrillar spatulas on gecko feet defy gravity primarily because of capillary forces present in the normal range of atmospheric humidity, which means "dry" in any meaningful clinical sense. ${ }^{3}$ Biochemistry was required to develop adhesive systems based on gecko foot architecture that work when wet. Indeed, the investigators recapitulated the amine-aldehyde covalent bonds produced by cyanoacrylates $^{4}$ on the path to a clever acrylated polymer that can be slathered on tissue in gel form, then crosslinked in seconds by applying ultraviolet light., ${ }^{5,6}$ Among other applications, these products show promise for adhesive patch closure of ventricular septal defects, ${ }^{7}$ and they are on the path to commercialization. In the competition over translations of foot architecture, will the upstart from class Cephalopoda knock out class Reptilia in the early rounds? Whatever the structural differences may be, it can be said that octopus suction cups evolved to work in a saline solution, and they could lead us toward flexible, wet-effective adhesives that are more mechanical and less chemical. 
I'd barely had time to finish my plate of calamari when another fascinating concept appeared in Science ${ }^{8}$ - a new family of tissue adhesives that was based on the physical chemistry behind the strong adherence to wet surfaces observed in the defensive mucus of slugs (Arion subfuscus). The mechanism of covalent bond formation is reminiscent of the cyanoacrylates and the gecko-inspired biodegradable elastomers ${ }^{4-7}$ except that the polyamines of slug mucus combine with carboxylic acid groups in a hydrogel matrix instead of combining with aldehydes. The 2-layer adhesive developed by Li and colleagues ${ }^{8}$ has an adhesive surface (which is based on the slug mucus mechanism) joined to a matrix that dissipates energy through hysteresis. This tissue adhesive formed strong, flexible bonds to a variety of wet surfaces. In an in vivo porcine beating-heart model in which fresh blood was spread on the epicardium, strong, durable bonds were formed $(83 \pm 31 \mathrm{kPa})$; these exceeded the strength of any commercially available tissue adhesives $(\sim 10 \mathrm{kPa})$.

I encourage anyone with an interest in biomaterials to peruse the reference list for in-depth discussions of intriguing variables and fascinating biophysical design considerations. The prizes go to those willing to follow their instincts and act on their inspirations.

\section{Conflict of Interest Statement}

Author has nothing to disclose with regard to commercial support.

\section{References}

1. Spiess K, Lammel A, Scheibel T. Recombinant spider silk proteins for applications in biomaterials. Macromol Biosci. 2010;10:998-1007.

2. Baik S, Kim DW, Park Y, Lee TJ, Bjang SH, Pang C. A wet-tolerant adhesive patch inspired by protuberances in suction cups of octopi. Nature. 2017;546:396-400.

3. Sun W, Neuzil P, Kustandi TS, Oh S, Samper VD. The nature of gecko lizard adhesive force. Biophys J. 2005;89:L14-7.

4. Mahdavi A, Ferreira L, Sundback C, Nichol JW, Chan EP, Carter DJ, et al. A biodegradable and biocompatible gecko-inspired tissue adhesive. Proc Natl Acad Sci U S A. 2008;105:2307-12.

5. Pereira MJ, Ouyang B, Sundback CA, Lang N, Friehs I, Mureli S, et al. A highly tunable biocompatible and multifunctional biodegradable elastomer. Adv Mater. 2013;25:1209-15.

6. Lang N, Pereira MJ, Lee Y, Friehs I, Vasilyev NV, Feins EN, et al. A bloodresistant surgical glue for minimally invasive repair of vessels and heart defects. Sci Transl Med. 2014;6:218ra6.

7. Roche ET, Fabozzo A, Lee Y, Polygerinos P, Friehs I, Schuster L, et al. A light reflecting balloon catheter for atraumatic tissue defect repair. Sci Transl Med. 2015;7:306ra149.

8. Li J, Celiz AD, Yang J, Yang Q, Wamala I, Whyte W, et al. Tough adhesives for diverse wet surfaces. Science. 2017;357:378-81. 